\title{
VIOLENCE AGAINST WOMEN COMMITED BY INTIMATE PARTNERS: (IN)VISIBILITY OF THE PROBLEM
}

\author{
Daniele Ferreira Acostaํ, Vera Lúcia de Oliveira Gomes², Adriana Dora da Fonseca ${ }^{3}$, Giovana Calcagno Gomes ${ }^{4}$
}

\footnotetext{
${ }^{1}$ Doctoral student in Nursing. FAPERGS Scholarship. Rio Grande, Rio Grande do Sul, Brazil. E-mail: nieleacosta@gmail.com.

2 Ph.D. in Nursing. Full Professor, School of Nursing, Universidade Federal do Rio Grande (FURG). Rio Grande, Rio Grande do Sul, Brazil. E-mail: vlogomes@terra.com.br

${ }^{3}$ Ph.D. in Nursing. Associate Professor, School of Nursing, FURG. Rio Grande, Rio Grande do Sul, Brazil. E-mail: adriana@ vetorial.net

${ }^{4}$ Ph.D. in Nursing. Dean of the School of Nursing, FURG. Rio Grande, Rio Grande do Sul, Brazil. E-mail: acgomes@mikrus. com.br
}

\begin{abstract}
The objective is to identify the reasons behind violence against women and describe the acts perpetrated by an intimate partner. Documentary study, qualitative conducted at the Special Police Service to Women. We analyzed 902 occurrences between August/ 2009 and December/2011, whose victims had at least eighteen years old. We collected the data of occurrences, transcribing literally, stories of the victims and treating it them through the content analysis. It was observed as triggers of violence: male supremacy as a generator of suffering and submission; problems arising from drug use, problems related to children and division of assets. The severity was scaled for the consequences to the victim and their family. The nursing staff as part of the support network, need to understand this phenomenon as a health problem and strive to break through the barriers that impede effective and efficient service, assisting in the strengthening of women's autonomy and including men in combat actions and prevention of violence against women. DESCRIPTORS: Domestic violence. Violence against women. Gender and health. Nursing. Public health.
\end{abstract}

\section{VIOLÊNCIA CONTRA A MULHER POR PARCEIRO ÍNTIMO: (IN) VISIBILIDADE DO PROBLEMA}

\begin{abstract}
RESUMO: Objetiva-se identificar os motivos que desencadeiam a violência contra mulher e descrever os atos perpetrados pelo parceiro íntimo. Pesquisa documental, qualitativa, realizada numa Delegacia Especializada de Atendimento às Mulheres. Analisaram-se 902 ocorrências registradas entre agosto/2009 e dezembro/2011, cujas vítimas tinham, no mínimo, dezoito anos. Colheram-se os dados das ocorrências, transcrevendo-se literalmente, os relatos das vítimas e tratando-os através da análise de conteúdo. Apreenderam como desencadeadores de violência: supremacia masculina como geradora de sofrimento e submissão; problemas decorrentes do uso de drogas; problemas relacionados aos(às) filhos(as); e problemas com divisão de bens. A gravidade foi dimensionada pelas consequências à vítima e família. A equipe de enfermagem, como integrante da rede de apoio, precisa compreender esse fenômeno como problema de saúde e empenhar-se para romper os obstáculos que impedem o efetivo e eficaz atendimento, auxiliando no fortalecimento da autonomia feminina e incluindo os homens nas ações de combate e prevenção à violência contra a mulher.
\end{abstract}

DESCRITORES: Violência doméstica. Violência contra a mulher. Gênero e saúde. Enfermagem. Saúde pública.

\section{VIOLENCIA CONTRA LAS MUJERES EN LA PAREJA: (IN)VISIBILIDAD DEL PROBLEMA}

RESUMEN: El objetivo del estudio fue identificar las razones que llevan a la violencia contra la mujer y describir los actos perpetrados por su pareja. Investigación documental, cualitativa realizada en el Servicio de Policía Especializada en Atención a Mujeres. Se analizaron 902 informes registrados entre Agosto/2009 y Diciembre/2011, cuyas víctimas tenían al menos dieciocho años. Se recolectaron los datos de las ocurrencias, describiendo literalmente, las historias de las víctimas y su tratamiento fue a través del análisis de contenido. Fue identificados como factores desencadenantes de la violencia: la supremacía masculina como generadora de sufrimiento y sumisión, los problemas derivados del uso de drogas, los problemas relacionados con los niños y la división de los bienes. La gravedad fue escalada por las consecuencias a la víctima y su familia. El personal de enfermería como parte de la red de apoyo, debe entender este fenómeno como un problema de salud y esforzarse por romper las barreras que impidan el servicio eficaz y eficiente, auxiliando en el fortalecimiento de la autonomía de las mujeres, incluyendo a los hombres en acciones de combate y prevención de la violencia contra las mujeres.

DESCRIPTORES: Violencia doméstica. Violencia contra la mujer. Género y salud. Enfermería. Salud pública. 


\section{INTRODUCTION}

Violence against women has been addressed as a public heath problem both due to the negative impact it has on the victims' quality of life and implications in the legal, economic, social and health spheres. Despite its acknowledged multidisciplinary nature, researchers highlight the social invisibility of this phenomenon, which is often attributed to the silence of victims and communication impasses between the victim and professionals. $^{1}$

The identification of epidemiological aspects and forms of violence against women enabled verifying that the main perpetrator of violent actions is the intimate partner himself. ${ }^{2-3}$ This context, surrounded by inequalities, is a result of historicalcultural issues arising from the organization of society that justifies the domination of women by men. ${ }^{4}$ In this sense, the culture conveyed by the family, "naturally" legitimated relations of power, gender and sexuality, making the domestic sphere a fertile ground for the practice of violence. ${ }^{5}$

Violence against women is any genderbased act or behavior that causes death, physical, sexual or psychological harm or distress, in either the private or public spheres. ${ }^{6}$ This phenomenon became more visible in the 1980s due to feminist campaigns and protests. There were numerous demands for safety and public policies supporting justice, through which women rebelled against the impunity of murderers, generally committed by partners or ex-partners, on the ground of legitimate defense of honor. ${ }^{7}$ This movement is reflected nationally and internationally, triggering major advancements in regard to preventing and combating this type of violence.

Law 11.360/2006, known as the Maria da Penha Law, is a Brazilian law that is intended to restrain and prevent domestic and family violence. ${ }^{8}$ Despite this legal protection, the number of female victims is still significant. Records show that $70 \%$ of the incidents occur at home and the husband or partner is the primary aggressor; more than $40 \%$ of violent acts result in bodily injuries as a consequence of punches, slaps, kicks, burns, or beatings. ${ }^{9}$ The magnitude of the problem, however, is much greater since many victims remain silent and numerous cases are not reported, which masks epidemiological data.

Additionally, few professionals report actual ${ }^{10}$ or presumed violence, even though they occupy a strategic position to detect this sort of event $^{10-11}$ and to provide assistance and refer victims to specialized services. It is worth noting that healthcare providers, especially nursing workers, are obliged to report violence under penalty of punishment provided in the relevant codes of ethics. One international study calls this invisibility of the problem, on the part of healthcare workers, a "conspiracy of silence". ${ }^{12}$

Nonetheless, there are many obstacles that impede attention being paid to women experiencing violence, either due to professionals' lack of preparation, ${ }^{12}$ lack of time, fear, prejudice against cultural stereotypes, or due to believing this is not a health problem. ${ }^{11}$ It is known that a qualified, cohesive, multidisciplinary team sensitive to the issue is required to address the problem due to its complexity. Isolated actions or professions acting in isolation are unlikely to succeed in fighting violence against women. ${ }^{13}$

In nursing discussing ways care is provided to victims is necessary in order "to deepen knowledge that encourages reflection upon nursing practice - what to do? How to do it? and Why do it? - so that this understanding is unique and specific" ${ }^{14: 156}$ It is necessary to recreate language based on the disease and face social problems as phenomena that interfere in health, enabling news forms to provide care.

It is believed that contact with the victims when they are at the height of their frustration and disclose all about the violent events contributes to understanding the severity of the phenomena and to enticing the commitment of nursing professionals so as to overcome the obstacles that impede effective and efficacious care being provided to women in situations of violence. The role of nurses concerning actions implemented among victims is to welcome these women, provide attentive listening, be sensitive to their complaints, and provide guidance in regard to their rights so that they are able to make conscious decisions.

Given the previous discussion and aiming to improve the quality of life of this population, as well as to contribute to the nursing staff in the identification and recognition of harm that results from violence against women, this study's objectives were to identify the factors that lead to the practice of violence and describe violent acts committed by intimate partners against women who complained to the Women's Police Station (WPS) in Rio Grande, Rio Grande do Sul, (RS), Brazil. 


\section{METHOD}

This documentary study with a qualitative approach was conducted in the Women's WPS in Rio Grande - RS, Brazil. Data were collected from 902 police reports of female victims aged 18 years old or older. The time frame was from August 2009, when this police station was instituted, to December 2011. Data were collected between October 2011 and March 2012. Four previously trained students collected data. They were mainly instructed to keep the confidentiality of data and of the names of those involved in the events.

An instruction manual was developed to standardize data collection, i.e., to ensure homogeneity of information. Using a laptop computer, data contained in the reports were transcribed verbatim, according to the victims' accounts. These transcriptions are identified by the letter "I" followed by a number corresponding to the order in which they were collected.

Content analysis was used to treat the data. ${ }^{15}$ First, we performed floating reading and prepared the material, which was followed by categorization, description and interpretation, when context units emerged. The project was approved by the Research Ethics Committee at the Universidade Federal do Rio Grande (FURG), Referee Report No. 137/2011.

\section{RESULTS AND DISCUSSION}

Of the 902 police reports, 676 (75\%) referred to violence committed by the victim's intimate partner, showing that, like other studies, marital violence predominates among women. ${ }^{2-3,11,14,16} \mathrm{It}$ is worth noting that this type of violence is extremely degrading considering it is committed by someone with whom the victim has or has had an intimateaffective relationship. Additionally, it mostly occurs at home; that is, the place that should be welcoming and comforting becomes the scenario for the practice of violent acts.

Numerical data were initially used to present the reasons triggering violent acts, because the "the quantity is always presented as a distinction within quality and quality is always presented in quantities, while quantity in itself is a quality of an object or reality." 17:96 Afterwards, each reason triggering violence was illustrated with the description of actions perpetrated against the complaints.

Analysis of the narratives contained in the reports revealed that diverse motives triggered violence and four categories emerged: male supremacy was a generator of suffering and submission (379); problems arising from the use of drugs (85); problems related to the couple's children (50); and problems arising from property settlements (32).

\section{Male supremacy was a generator of suffering and submission}

The naturalization of male power over the bodies and choices of women, which is a result of cultural stereotypes, has legitimated the practice of domestic violence. Hence, recognizing and acknowledging, without reflection or criticism, the authoritarian attitudes of men, such as violent manifestations of jealousy, disagreement over separation or filing a police complaint, ${ }^{10,18}$ encourages the perpetuation of violence. These excuses are seen in this study and are exemplified in the following excerpts.

He started to harass the victim from the time she wanted a separation, a month ago. He rips the victim's clothes, material from the school where she works. Victim is afraid for her and her children's lives (I 425).

She's been chased since separation, a year ago. She was grabbed, off guard, by the neck; he tried to strangle her when she was waiting for the bus and was saved by passers-by [...] (I 393).

The accused is unhappy with the separation and seeks the victim insistently. Sends emails and messages, seeks out relatives and friends to convince her to go back to him [...] (I 197).

The routinization of violence is one of the factors that motivates a woman to break off the relationship with her partner. ${ }^{16}$ Nonetheless, the individual not accepting the separation resorts to violence in an attempt to frighten the victim and make her give up. As a result, women feel unprotected, humiliated, and devalued, ${ }^{18}$ which may lead to the somatization of health problems. It is worth noting that this vulnerability negatively impacts one's self-esteem and self-image, leading to a greater propensity to accept victimization, ${ }^{9}$ or even to attempt suicide as a way to escape from abuse. ${ }^{12}$

Family support and support provided at a time of helplessness is essential. Even in that context, though, it is not uncommon for members of the social network itself to blame the woman for the event as a result of a culture that values hierarchical sexual patterns. ${ }^{19}$ In this sense, this inequality between genders, based on an asymmetry of power, influences "women's ways of living, becoming ill, and dying". ${ }^{11: 626}$ 
The exacerbation of male dominance does not negatively impact only the victim. As observed, the problem is extended to children involved, extended family, and the community, ${ }^{3}$ with economic, psychological, behavioral, interpersonal and professionals consequences.

The same happens when violence is triggered by jealousy, which is a sense of possession over the woman. ${ }^{10}$ Based on this feeling, the man usually states that if she is not his, she will be no one's.

The accused threatens, saying he will kill her with a knife. He is jealous and possessive, saying that if she does not stay with him, she will stay with no one else [...] (I 474).

When she was going to work, the husband implied that her clothes were saying she was dressed to meet another man. When she came back home, her clothes were torn, shoes were destroyed, make-up and flat iron broken, and her working papers were torn up (I 525).

These reports show the presence of patriarchal attitudes that impose and reaffirm control over women. Cases in which feelings of possession and moralism are exacerbated, and when there is aggressiveness motivated by jealousy, generally culminate in homicide. ${ }^{20}$ The results of this study can be confronted with male discourse that centralizes decision-making when they exert power over their partners by choosing their clothes, their friends, and whether they have the right to work. ${ }^{20-21}$

Psychological violence, though invisible, causes fear and insecurity in the victims, leading to apathy and making them vulnerable to other discrete violent actions or actions associated with other forms of violence, such as against patrimony, ${ }^{8}$ portrayed in the destruction of the victim's objects, working instruments, or personal documents.

Abuse of power may be identified when women are prevented from enjoying their freedom to come and go as they please. False imprisonment is a form of psychological violence accruing from male dominance.

She was kept at home, chained, for five days, without food; wearing only underwear so she would be cold. The [victim's] mother managed to freed her after receiving a call from the victim on the cellphone and then the mother was threatened by the aggressor. She [victim] was severely beaten and was bedridden for ten days because of the injuries (I 469).

This report shows the severity of this phenomenon that is often muted within homes. The woman becomes inert in the face of these situations and needs help to escape from violent acts. Other studies also show the severity of this phenomenon, revealing how domestic and marital violence affect the woman's sociability and productivity. ${ }^{3,11}$ Usually, beating, strangulation, slaps, and blows occur against women in marital conflicts, ${ }^{10}$ generating severe consequences on the health-disease continuum.

In developed countries such as Australia, Canada, and the United States, the costs involving assistance to women victimized by their intimate partners are examined through significant investments in healthcare services and criminal justice. ${ }^{3}$ Therefore, due to immediate traumas or secondary health problems, healthcare services emerge as the first places where victims can receive assistance and nursing workers are the healthcare professionals who experience these situations most closely. ${ }^{14}$ Nonetheless, everyone should become concerned with the phenomenon, seeking to identify and understand it more deeply in order to ensure that care provided to affected women is different from the hegemonic model ${ }^{11}$ that ends up re-victimizing them.

Male power is evidenced again, forcing the victim to maintain sexual intercourse regardless of her will, treating her as a sexual object.

He assaulted her when she denied him sex [...] he pulled her by the hair and slapped her twice when she said she was not feeling well enough to have sex. He said it was all bull (I 675).

Refusal to have sexual intercourse can be understood as a potential betrayal and a power struggle, triggering new arguments, aggressions, and sexual violence. ${ }^{21}$ Even though, in general, people believe that sexual crimes are mostly committed by strangers, there are studies reporting the prevalence of marital rapes. ${ }^{11}$

Despite all these factors, not all women take the initiative to break the cycle of violence or even to acknowledge their situation of submission. According to this study's findings and those reported by other studies, ${ }^{18,20}$ when women have the courage to report their partners, they are at the risk of being re-victimized under the threat of death or physical aggression. This behavior, on the part of the partners, reflects the restoration of the cycle of violence.

The victim is being threatened with death, and she is giving up protective measures. He broke into her house. She has been saved by family members from being beaten (I 403). 
He started threatening her, saying: 'beating you does no good because of the Maria da Penha [law], since I'll be in jail just the same, it's easier to kill you' (I 470).

He threatened her with death saying he's not afraid of the police or any judge, and did not comply with the legal action (I 496).

The reports also show that, for the aggressors, neither the police nor the law is capable of stopping them. The fact they are thwarted with an "order" also becomes a primary reason that aggressors indicate as a trigger of violence..$^{22}$ Hence, we question the effectiveness of current protective measures and punishment.

\section{Problems arising from the use of drugs}

There is an interaction of elements influencing behavior, increasing or decreasing one's likelihood of becoming a victim or aggressor. ${ }^{2,23}$ In this sense, individual factors, such as the use of drugs, have been referred to as capable of triggering violence according, to victims' reports.

The accused left home to drink and came back drunk. They started to fight and he said he would kill her and punched her in the face. The threats continued and he locked her in the bedroom [...] (I 578).

There is evidence that the use of drugs, legal or illegal, is often present in the context of violence against women. ${ }^{2,22-23}$ Studies show that alcohol weakens the user's inhibitions, contributing to the manifestation of violence. ${ }^{2}$ It is believed that this disinhibiting effect is responsible for the outbreak of aggression. Some men use this excuse for their violent behaviors. Other times, they hold the woman responsible for their violent behavior, as they do not accept the woman's interference in their habits. ${ }^{22}$

The victim scolded him [aggressor] for drinking, so he punched and kicked her, and dragged her by the hair [...] (I 240).

In regard to illegal drugs, the use of crack has been accounted as a substance that promotes violence. ${ }^{23}$ This drug has individual, legal and social implications ${ }^{2}$ associated with the need to support chemical dependence.

Because of the use of crack, he physically attacks her, usually locks her at home with the children and sells their belongings (I 192).

The accused forces the victim to give him money and steals and sells objects from her house to buy drugs [...] (I 671).

Selling belongings is a common way to finance the aggressor's vices and maintain the consumption of drugs. Hence, in the face of the aggressor's violent behavior, and consequent fear and insecurity on the part of the victim, ${ }^{23}$ a barrier impeding communication between both settles in. Women living with drug-users, whether legal or illegal drugs, are at a great risk of becoming victims.

\section{Problems related to the couple's children}

Among the various reasons triggering violence, issues related to children's custody and visitation, children's financial support, and the mother's attempt to protect them from the father's aggression, most often appear as triggering violence.

The accused went to return the child and when she complained about the hour he punched her (I 345).

The aggressor went to the victim's house to take the daughter but the mother would not authorize it, so he punched her in the face and left her unconscious (I 355).

He [accused] pursues her. He broke into the courtyard and threatened to kill her, demanding that she withdraw from the financial support process. He says he will buy a gun and kill the victim [...] (I 582).

The prescription of family roles over time was responsible for dictating patriarchal values according to a rigid and traditional division of roles. ${ }^{9}$ Men were the breadwinners responsible for providing, while women were responsible for taking care of the home, for raising and taking care of children. In this sense, the right of mothers to have custody of children was legitimated in cases of marital separation. ${ }^{8}$

In the face of male supremacy, which responds with violence, however, it is difficult for women to exert autonomy in the case of divergent opinions, especially when it involves children indirectly exposed to and victimized by marital conflicts, with consequences for life. We ask: what is the psychological state of a child who watches the father so brutally assault the mother? Witnessing violence may perpetuate violent behavior, leading to the maladjustment of children and adolescents and affecting their education and development. ${ }^{3,9}$

The protective measures to avoid these upheavals available to the woman who experiences domestic violence and reports the aggressor include restricted or suspended visitation of the father with minor children and his obligation to provide for the children. ${ }^{8}$ Additionally, the legitimation of the woman's caretaker role reinforces the attention and protection she grants to children, exemplified in the following report: 
He cursed the victim, broke objects in the home, and he was going to beat the child and ended up beating the victim because she stepped in (I 373).

It is because of children that many women take the initiative to break the cycle of violence and report the aggressor Additionally, in the face of so much suffering, there are women who leave their house aiming to achieve a peaceful and happy life together with their children. ${ }^{16,20}$

\section{Problems arising from property settlements}

Problems concerning the division of property are part of this context and also trigger violence against women.

They started arguing when a discussion regarding division of property was initiated. They are separated but live in the same house. He verbally abused her and punched her in the face, saying that if he had to leave the house he would set it on fire (I 575).

He says he will not leave the house. She is the one who has to seek another place to live, though the place belongs to both. He pulled her hair and threw her out of the house, kicking and punching her, which resulted in bruised arms, legs and neck (I 656).

Male domination is expressed in many forms of violence. Specifically, in these cases, the man attempts to take the woman out of areas and places he considers to be his domain, through physical aggression and threats. As he believes himself to be superior, he thinks he has the right to control the couple's property, threatening to expel the woman out of the house. ${ }^{1}$

Authors assert that when victims of violence are isolated from their kinship networks and from community, they are more exposed to the control of aggressors. ${ }^{9}$ Women living with abusive partners are supported by the Maria da Penha Law that establishes that the aggressor is required to leave the house and keep away from the victim and her family. ${ }^{8}$ For that, law enforcement officers need to be qualified in legal and police terms to break from prejudices, ${ }^{19}$ in order to provide humanized assistance and instruct the victims regarding their rights.

\section{FINAL CONSIDERATIONS}

This study's results reveal that regardless of the characterization of factors that trigger violence against women, most are a result of a feeling of possession and male domination. Additionally, this phenomenon is very severe, not only because of how frequently it occurs, but also because of the repercussions for the victims and families.

Different forms of violence harm human rights and ratify the need for a cohesive support network with a multidisciplinary approach, with professionals qualified to identify violence, orient and effectively intervene in women's health and disease continuum. For that, it is first necessary to break from cultural barriers and prejudice in order to welcome and assist the victims.

Different forms of violence occur simultaneously, so nursing staff needs to recognize injuries and harm, understanding that violence goes beyond the biological sphere, providing humanized care that comprehends the women's psychological, social and spiritual dimensions. Understanding the dynamics of violence perpetrated against women contributes to reflective and effective nursing practice, in agreement with the needs of the victim and her family.

Additionally, preventive and educational actions valuing women and encouraging dialogue to solve conflicts and promote family ties are essential to coping with this phenomenon. The problem will not be solved, however, if interventions exclusively focus on women. Hence, we stress the need to include men in actions intended to fight and prevent violence against women.

This study presented the factors that trigger violence, describing the acts committed by intimate partners. We expect this information to support the healthcare staff, especially nursing workers, in the identification of vulnerable women and encourage interventions on the part of the society and other professionals, and to prompt legislators to implement efficacious public policies necessary to cope with and combat violence against women.

\section{REFERENCES}

1. Schraiber L, Oliveira AF, Hanada H, Figueiredo W, Couto M, Kiss L, et al. Violência vivida: a dor que não tem nome. Comunic Saúde Educ. 2003 Fev; 7(12):41-54.

2. Krug EG, Dahlberg LL, Mercy JA, Zwi AB, Lozano R, organizadores. World report on violence and health. Geneva (SW): World Health Organization; 2002.

3. Duvvury N, Grown C, Jennifer Redner. Estimating the costs and impacts of intimate partner violence in developing countries: a methodological resource guide. Washington: International Center for Research on Women; 2009 [acesso 2012 Abr 29]. Available at: http://www.icrw.org/files/ 
publications/Estimating-the-Costs-and-Impactsof-Intimate-Partner-Violence-in-DevelopingCountries-A-Methodological-Resource-Guide.pdf

4. Scott J. Gênero: uma categoria útil de análise histórica. Educ Realidade. 1995 Jul-Dez; 20(2):71-99.

5. Meyer DE. Corpo, violência e educação: uma abordagem de gênero. In: Junqueira RD, organizador. Diversidade sexual na educação: problematizações sobre a homofobia nas escolas. Brasília (DF): MEC; 2009. p. 213-34.

6. Brasil. Convenção Interamericana para Prevenir, Punir e Erradicar a Violência Contra a Mulher "Convenção de Belém do Pará". Adotada em Belém do Pará, Brasil, em 9 de junho de 1994, no Vigésimo Quarto Período Ordinário de Sessões da Assembléia Geral. Comissão Interamericana de Direitos Humanos. Belém (PA); 1994

7. Pasinato $\mathrm{W}$, Santos CMD. Mapeamento das Delegacias da Mulher no Brasil. São Paulo (SP): Universidade de Campinas; 2008.

8. Brasil. Lei n. 11.340 de 7 de agosto de 2006. Lei Maria da Penha. Dispõe sobre mecanismos para coibir a violência doméstica e familiar contra a mulher. Brasília (DF): Câmara dos deputados, Coordenação de Publicações; 2007.

9. Narvaz MG, Koller SH. Mulheres vítimas de violência doméstica: compreendendo subjetividades assujeitadas. PSICO. 2006 Jan-Abr; 37(1):7-13.

10. Carvalho C, Destro JR, Faust SB, Coelho EBS, Boing AF. Dinâmica da violência entre casais a partir da ótica da mulher agredida no bairro Trindade, Florianópolis/SC. Cogitare Enfer. 2010 Out-Dez; 15(4):603-8.

11. Guedes RN, Silva ATMC, Fonseca RMGS. A violência de gênero e o processo saúde-doença das mulheres. Esc Anna Nery Rev Enferm. 2009 Jul-Set; 13(3):625-31.

12. Yee A. Reforms urged to tackle violence against women in India. Lancet [online]. 2013 [acesso 2012 Abr 29]; 381(19876):1445-6. Available at: http:// www.lancet.com/journals/lancet/article/PIIS0140$6736 \% 2813 \% 2960912-5 /$ fulltext
13. Schraiber LB, Oliveira AFPL, Couto MT. Violência e saúde: contribuições teóricas, metodológicas e éticas de estudos da violência contra a mulher. Cad Saúde Pública. 2009; 25(sup2): 205-16.

14. Morais SCRV, Monteiro CFS, Rocha SS. O cuidar em enfermagem à mulher vítima de violência sexual. Texto Contexto Enferm. 2010 Jan-Mar; 19(1):155-60.

15. Bardin L. Análise de conteúdo. Lisboa (PT): Edições 70; 2011.

16. Vieira LB, Padoin SMM, Souza IEO. Perspectivas para o cuidado de enfermagem às mulheres que denunciam a violência vivida. Esc Anna Nery. 2011 Out-Dez; 15(4):678-85.

17. Minayo MCS, organizadora Caminhos do pensamento: epistemologia e método. Rio de Janeiro (RJ): Fiocruz; 2002.

18. Ribeiro DKL, Duarte JM, Lino KC, Fonseca MRCC. Caracterização das mulheres que sofrem violência doméstica na cidade de São Paulo. Saúde Colet. 2009; 6(35):264-68.

19. Santi LN, Nakano MAS, Lettiere A. Percepção de mulheres em situação de violência sobre o suporte e apoio recebido em seu contexto social. Texto Contexto Enferm. 2010 Jul-Set; 19(3):417-24.

20. Lamoglia CVA, Minayo MCS. Violência conjugal, um problema social e de saúde pública: estudo em uma delegacia do interior do Estado do Rio de Janeiro. Ciên Saúde Coletiva. 2009; 14(2):595-604.

21. Gomes NP, Diniz NMF. Homens desvelando as formas da violência conjugal. Acta Paul Enferm. 2008; 21(2):262-7.

22. Deeke LP, Boing AF, Oliveira WF, Coelho EBS. A dinâmica da violência doméstica: uma análise a partir dos discursos da mulher agredida e de seu parceiro. Saúde Soc. 2009; 18(2):248-58.

23. Trigueiro TH, Labronici LM. Chemical dependency as a risk factor for domestic violence against women. Online Braz J Nurs [online]. 2011 [acesso 2012 Abr 29]; 10(2):1-9. Available at: http:/ / www.objnursing. uff.br/index.php/nursing/article/view/3266/html 